\title{
ISLAMIC CORPORATE GOVERNANCE DAN KINERJA KEUANGAN UNIT USAHA SYARIAH (UUS)
}

\author{
Lenny Mardiani \\ Winwin Yadiati \\ winwin.yadiati@fe.unpad.ac.id \\ Eddy Jaenudin
}

Universitas Padjadjaran

\begin{abstract}
ABSTRAK
Penelitian ini bertujuan untuk mengetahui pengaruh pengungkapan Islamic Corporate Governance (ICG)dan Intellectual Capital (IC) terhadap kinerja keuangan UUS . Pengungkapan ICG diukur menggunakan pedoman Good Governance Bisnis Syariah (GGBS) yang dikeluarkan KNKG (2011), Intellectual Capital diukur dengan iB-VAIC (Ulum,2013) dan kinerja keuangan diukur dengan rasio profitabilitas, yaitu ROA. Penelitian ini adalah penelitian deskriptif dengan pendekatan kuantitatif. Sampel penelitian ini terdiri dari 18 UUS dari periode 2013-2017. Data sekunder diambil dari annual reportdan laporan keuangan triwulan ke-IV khusus UUS dari bank konvensional induk yang kemudian dianalis secara statistik dengan menggunakan metode analisis regresi data panel. Hasil penelitian menunjukka bahwa ICG tidak berpengaruh terhadap kinerja keuangan UUS danIntellectual Capital berpengaruh positif signifikan terhadap kinerja keuangan UUS.
\end{abstract}

Keywords : Islamic Corporate Governance, Intellectual Capital,

\section{PENDAHULUAN}

Keberadaan bank Islam di Indonesia dipelopori oleh bank Muamalat yang berdiri pada tahun 1992. Muamalat terbukti mampu bertahan saat terjadi krisiskeuangan global 1998 dan kemudian mendorong pemerintah menyempurnakanaturan mengenai bank Islam di Indonesia. Pemerintah membuat peraturan yangmenegaskan bahwa Indonesia menganut dual banking system untuk sistem perbankannya. Hal tersebut disambut oleh bank konvensional Indonesia denganberlomba-lomba membentuk Unit Usaha Syariah (UUS) untuk mengembangkan usahanya.Sejak saat itu, tercatat hingga tahun 2017 telah ada 13 BUS dan 21 UUS dengan total 1.966 kantor yang beroperasi di Indonesia (SPS, 2017).

Meskipun di Indonesia telah banyak segmen usaha yang menerapkan sistem keuangan syariah, namun perbankan syariah adalah yang paling dominan berkontribusi terhadap tumbuhnya keuangan syariah.Namun, perkembangan perbankan syariah yang pesat tidak serta merta sejalan dengan peningkatan market share perbankan syariah Indonesia. Perbankan syariah Indonesia hanya mampu memperoleh market share sebanyak 5,44\% dari total market share perbankan nasional (OJK, 2017).Perolehantersebut terbilang kecil jika dibandingkan dengan market share di negara-negara lain, misalnya Malaysia 23,8\%, Arab Saudi 51,1\%, dan Uni Emirat Arab 19,6\%. Denganmayoritas penduduk yangberagama Islam, seharusnya market shareIndonesia dapat mengungguli perolehanmarket share negara-negara tersebut. Lambatnya pertumbuhan perbankan syariah diduga disebabkan oleh kualitas bankbank Islam di Indonesia yang belum membaik terutama UUS yang beroperasi dibawah naungan 
bank konvensional. Hal inimenimbulkan keraguan bagi stakeholders yang berdampak pada timbulnya persepsi negatif mengenai sistem dan prinsip-prinsip syariah yang diterapkan bank Islam. Mereka menilai bahwa bank Islam tidak secara konsisten menerapkan syariat Islam dan efisien dalam mengelola asetnya karena bercampur dengan aset bank induknya, sehingga enggan untuk menyimpan dana dan menggunakan produk dan jasa yang ditawarkan oleh bank-bank Islam.

UUS harus memperbaiki reputasinya dan membangun citrameski beroperasi dibawah naungan bank konvensional, prinsip-prinsip Islam dapat diterapkan dengan baik dan dapat secara efisien mengelola aset-asetnya. Oleh sebab itu UUS harus menunjukkan kinerja yang baik kepada stakeholders. Kualitas UUS yang belum baik karena beroperasi dibawah naungan bank konvensional menyebabkan UUS mengalami kesulitan untuk bersaing dan berkembang dalam industri perbankan nasional. Untuk meningkatkan ketaatan bank syariah pada prinsip syariah dan mendorong percepatan pertumbuhan perbankan syariah di Indonesia(Al-Arif et al., 2017), pemerintah kemudian mewajibkan bank konvensional untukmelakukan pemisahan (spin-off) dengan UUS paling lambat 15 tahun setelah peraturan tersebut disahkan, yaitu pada tanggal 16 Juli 2008. UUS diarahkan untuk membentuk bank syariah yang baru atau bergabung dengan bank syariah yang sudah ada gar dapat beroperasi dengan ruang lingkup usaha yang lebih luas dan leluasa mengelola aset-asetnya.

Sejak diberlakukannya aturan tersebut, sudah ada beberapa bank konvensional yang melakukan spin-off. Namun, setelah beroperasi sebagai bank syariah secara utuh muncul indikasi bahwa bank-bank hasil spin-off belum cukup kuat dalam menghadapi persaingan di industri perbankan nasional karena target bahwa market shareakan meningkat secara signifikan masih belum tercapai, terjadi penurunan kinerja bank dalam menghasilkan aset, menyalurkan pembiayaan, penurunan pertumbuhan dana simpanan di bank syariah dalam beberapa tahun terakhir, danterjadi penurunan efisiensi operasional di bank Islam hasil spinoff(Al-Arif et al., 2017). Disamping itu, belum satupun UUS yang dinilai layak untuk spin-off karenarasio total aset UUS yang tidak mencapai 50\% dari total aset bank konvensional induk. Kondisi ini jelas memperlihatkan bahwa UUS belum efisien mengelola asetnya dalam menciptakan laba. Jika dibiarkan terus begituakan menyebabkan bank konvensional terkendala modal saat melakukan spin-off karena harus menyetorkan modal yang besar untuk membentuk bank syariah yang baru, terlebih lagi bagi bank konvensional yang tidak memiliki aset besar.

Dikhawatirkan, jika saat masih berbentuk UUS saja mereka tidak mampu mengelola asetnya secara efisien, maka ketika nanti sudah menjadi bank syariah dengan lingkup usaha yang lebih luas dan persaingan yang ketat mereka akan mengalami kesulitan untuk tumbuh dan berkembang (Al-Arif et al., 2017). Oleh sebab itu, dibutuhkan usaha yang lebih keras dari UUSuntuk mempersiapkan diri menghadapi persaingan yang ketat setelah spin-off danmencukupi modalnya untuk bisa melakukan spin-off. Untuk memperbaiki kualitas perbankan syariah agar reputasinya dapat ditingkatkan dan kelangsungan usahanya dapat terjaga, Bank Indonesia selaku regulator mewajibkan bank syariah untuk menerapkan Good Corporate Governance (GCG) dan secara transparan mengungkapkan informasi terkait itu dalam annual reportbagi bank syariah maupun unit usaha syariah. Albassam et al., (2017) menyatakan bahwa pengungkapan terkait corporate governance yang transparan dan akuntabel adalah salah satu cara yang dapat digunakan oleh bank Islam untuk menampilkan kualitas tata kelola perusahaan yang mereka terapkan dan dapat memperbaiki reputasi mereka di hadapanstakeholders. Selain penerapan konsep ICG yang sesuai dengan prinsip syariah, kinerja dari Intellectual Capital (IC) yang melekat erat pada sumber daya manusia yang bekerja untuk bank Islam juga dinilai penting untuk meningkatkan kinerja bank Islam di Indonesia.Sumber daya manusi yang memiliki pengetahuan, keterampilan, dan kemampuan 
dapat dimanfaatkan oleh bank untuk berinovasi dalam hal produk, proses, pemasaran, dan organisasi agar dapat mengcover berbagai kebutuhan nasabah (Kalkan et al, 2014).

UUS harus melakukan evaluasi terhadap ICG dan IC tersebut untuk memonitor bagian mana yang perlu diperbaiki dan ditingkatkan untuk menghasilkan nilai tambah lebih besar di masa mendatang dan dapat dijadikan bahan pertimbangan bagi manajemen untuk menyusun strategi yang tepat sehingga UUS dapat menunjukkan citra walaupun beroperasi dibawah naungan BUK, namun bisnis UUS dapat dijalankan sesuai dengan prinsip syariah dan dikelola dengan baik oleh SDM yang berkualitas dan dapat tumbuh secara sehat, kuat, dan efisien (Maradita, 2014).

\section{LITERATURE REVIEW}

\section{Islamic Corporate Governance}

Banyak penelitian yang berfokus pada pengaruh penerapan ICG terhadap kinerja keuangan pada bank syariah, namun masih terdapat perbedaan dari hasil penelitian-penelitian tersebut. Farag et al., (2017); Yadiati et al., (2017) menemukan bahwa penerapan ICG berpengaruh positif terhadap kinerja keuangan bank syariah. Sedangkan, penelitian yang dilakukan oleh Ferdiyant et al (2014) menemukan bahwa penerapan ICG berpengaruh negatif terhadap kinerja keuangan bank syariah. Berbeda dengan penelitian yang menyatakan ICG berpengaruh terhadap kinerja keuangan bank syariah, penelitian Ajili dan Bouri (2018); Siswanti (2016); Novitasary dan Permatasari (2014);Hassan Al-Tamimi(2012) justru menemukan bahwa ICG berpengaruh tidak signifikan terhadap kinerja keuangan bank syariah. Hingga saat ini belum ada pemahaman terpadu yang jelas tentang Islamic Corporate Governance; model ICG diusulkan dengan merekonsiliasi tujuan hukum Syariah dengan model stakeholder tata kelola perusahaan. Model ini layak karena penekanan bahwa hukum Syariah menempatkan pada properti dan hak kontraktual keuangan Islam (Bhatti dan Bhatti, 2010). Choudury dan Hoque dalam Hasan (2009) menyatakan bahwa konsep ICG tidak berbeda jauh dengan definisi GCG di konvensional karena sama-sama mengacu pada sistem di mana perusahaan diarahkan dan dikendalikan dengan tujuan untuk memenuhi tujuan perusahaan dengan melindungi semua kepentingan dan hak pemangku kepentingan. Yang membedakannya adalah dalam paradigma Islam CG mengacu sebagai kasus khusus dari teori pengambilan keputusan yang lebih luas yang menggunakan premis epistemologi sosio-ilmiah Islam yang didasarkan pada Tuhan Yang Maha Esa.

El Junusi (2012) berpendapat bahwa yang membedakan antara implementasi Good Corporate Governance (GCG) pada perbankan syariah dan konvensional terletak pada shariah compliance (kepatuhan pada syariat Islam). Sedangkan prinsip-prinsip transparansi, kejujuran, kehati-hatian, dan kedisiplinan merupakan prinsip universal yang juga terdapat dalam aturan GCG konvensional.Maka dapat disimpulkan bahwa Islamic Corporate Governance adalah sistem yang saling berhubungan mencakup proses dan struktur yang digunakan dalam suatu perusahaan untuk mengarahkan, mengelola, dan mengendalikan bisnis secara transparan dengan mengacu pada prinsip-prinsip Islam yang tidak hanya untuk meningkatkan akuntabilitas dan nilai tambah bagi pemegang saham dan stakeholder perusahaan tetapi juga akuntabilitas kepada Tuhan Yang Maha Esa.

Penelitian mengenai pengungkapan ICGpada bank Islam didasari oleh Agency Theory dan Sharia Enterprise Theory (SET). Safieddine dalam Abdullah et al., (2015) berpendapat bahwa bank Islam menghadapi agency problem berbeda dari yang biasa dihadapi bank konvensional karena di bankIslam, nasabah yang meminjam, menginvestasikan dan menyimpan dananya ikut menjadi bagian dari konflik agensi karena mereka berpartisipasi dalam laba dan rugi sama halnya dengan pemegang saham (Darmadi, 2013). Tata kelola perusahaan bank syariah juga harus didasari oleh pemenuhan tanggung jawab tidak hanya 
kepada manusia dan Alam melainkan kepada penguasa tertinggi, yaitu Allah SWT.Sharia Enterprise Theory menurut Slamet (Triyuwono, 2012) menjelaskan bahwa kebenaran terpenting yang harus mendasari setiap penetapan konsepnya adalah Allah SWT sebagai Pencipta dan Pemilik Tunggal dari seluruh sumber daya yang ada di dunia ini. Pengetahuan tentang struktur tata kelola perusahaan akan berguna bagi pemangku kepentinganuntuk menilai kredibilitas informasi keuangan, serta untuk secara akurat menetapkan harapan dan mengurangi ketidakpastian mengenai kinerja perusahaan (Bhat et al., 2006dalam Darmadi, 2013).

\section{Intellectual Capital}

Beberapa penelitian terdahulu menguji secara empiris pengaruh Intellectual Capital terhadap kinerja keuangan dan menghasilkan penemuan yang berbeda. Misalnya, penelitian yang dilakukan oleh Sunardi (2017); Ozkan et al (2017); Rini dan Boedi (2016) dan Dewanata et al (2016) menemukan bahwa seluruh komponen IC yang diukur dengan model VAIC berpengaruh positif dan signifikan terhadap kinerja keuangan bank syariah. Berbeda dengan yang Al-Musali dan Ismail (2014); Nawaz dan Haniffa (2017) menemukan bahwa Human Capital (HC) dan Capital Employed (CE) berpengaruh positif terhadap kinerja keuangan bank syariah, sedangkan Structural Capital (SC) tidak berpengaruh terhadap kinerja keuangan bank syariah.

Intellectual capital dapat diartikan sebagai pengetahuan yang dapat digunakan seluasluasnya untuk menghasilkan keuntungan atau tujuan lainnya (Habiburrachman, 2008). Intellectual capital dimaksudkan juga sebagai keahlian yang digunakan perusahaan dalam proses produksi barang dan jasa untuk meningkatkan nilainya termasuk hasil dokumentasi mengenai pemasok, pelanggan, hasil penelitian dan informasi penting lainnya yang bermanfaat memberi nilai tambah pada perusahaan(Habiburrachman, 2008).

Ulum (2013) mendefinisikan intellectual capital dalam artikelnya "modal intelektual adalah materi intelektual pengetahuan, informasi, hak pemilikan intelektual, pengalaman yang dapat digunakan untuk menciptakan kekayaan."Stewart (1997) dalam Kalkan et al., (2014) mendefinisikan intellectual capital sebagai total stok pengetahuan kolektif, informasi, teknologi, hak kekayaan intelektual, pengalaman, pembelajaran dan kompetensi organisasi, sistem komunikasi tim, hubungan pelanggan, dan merek yang mampu menciptakan nilai bagi suatu perusahaan.

Intellectual Capitalsecara konsistenterdiri dari tiga komponen utama (Pulic, 2000; Bontis et al., 2000; Ulum, 2013), yaitu pertama, Human Capital yang menggambarkan knowledge, experience, dan competence yang bersumber dari karyawannya dan akan menghasilkan inovasi dan solusi dalam menghadapi suatu permasalahan. Kedua, Structural Capital yang mempresentasikan sistem operasional, budaya perusahaan, infrastruktur, dan lain sebagainya yang mendukung karyawan untuk menghasilkan kinerja yang berpengaruh besar untuk pencapaian tujuan perusahaan. Dan Ketiga, Capital Empeloyed yang mempresentasikan hubungan perusahaan yang seluruh mitranya di luar perusahaan, baik deposan, supplier, pemerintah, maupun masyarakat disekitar wilayah operasionalnya. Penelitian mengenai pengeloaan Intellectual Capital pada Unit Usaha Syariah ini didasari oleh Resource Based Theory (RBT). RBT membahas mengenai sumber daya berupa aset berwujud dan aset tidak berwujud yang dimiliki oleh suatu perusahaan dan bagaimana perusahaan tersebut mengelola dan memanfaatkan sumber daya tersebut untuk menghasilkan nilai tambah bagi perusahaan untuk kepentingan para pemangku kepentingan.Intellectual Capital merupakan aset tidak berwujud yang mencangkup semua pengetahuan karyawan, organisasi, dan kemampuan mereka untuk menciptakan suatu nilai tambah (value added) bagi perusahaannya dan menyebabkan perusahaan dapat memiliki keunggulan dalam bersaing seperti yang disebut Chen et al (2005). Keunggulan kompetitif perusahaan akan menjadi nilai lebih dibandingkan 
dengan perusahaan lain sehingga kondisi tersebut dapat memberikan kontribusi terhadap kinerja keuangan atau profitabilitas

\section{Hipotesis dan Kerangka Pemikiran}

H1 : Semakin baik pengungkapan Islamic Corporate Governance, maka akan semakin tinggi tingkat kinerja keuangan yang dapat dicapai oleh Unit Usaha Syariah Periode 2013-2017.

H2 : Semakin baik pengelolaan intellectual capital, maka akan semakin baik kinerja keuangan yang dapat dicapai olehUnit Usaha Syariah Periode 2013-2017.

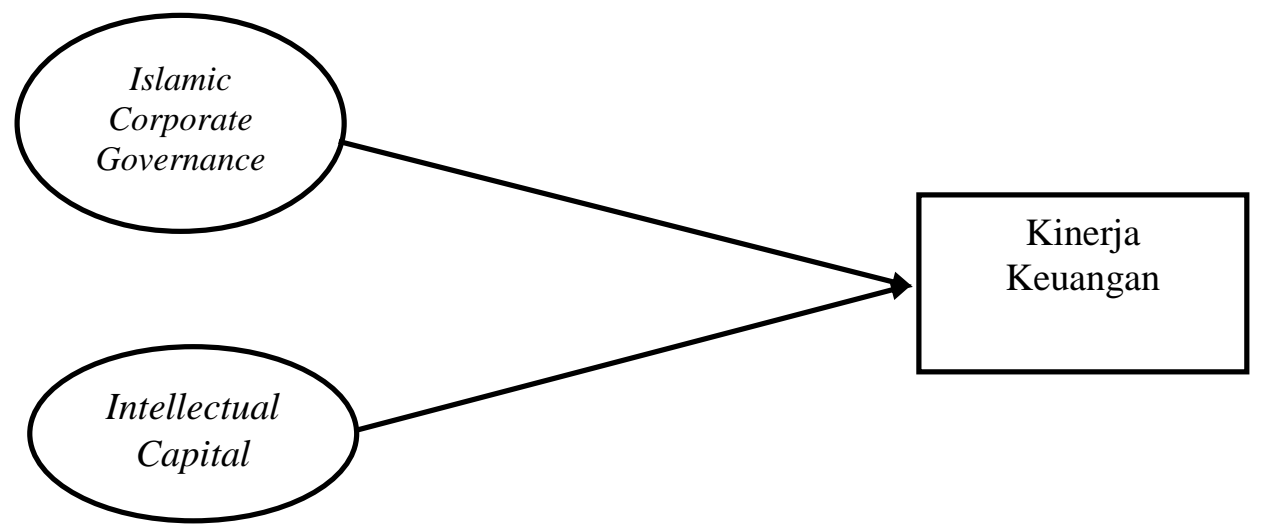

Gambar 1 Kerangka Pemikiran

\section{METODE PENELITIAN}

Objek dalam penelitian ini adalah pengaruh Islamic Corporate Governance dan Intellectual Capital terhadap kinerja keuangan Unit Usaha Syariah (UUS) yang dimiliki bank umum konvensional di Indonesia selama periode 2013-2017.Populasi dalam penelitian ini adalah seluruh UUS yang dimiliki BUK di Indonesia yang berjumlah 21 unit dan setelah dilakukan pengumpulan data diperoleh 18 UUS yang dijadikan sampel dengan alasan ketersedian data. 18 UUS tersebut terdiri dari:

\section{Tabel 1}

Sampel Penelitian

\begin{tabular}{|c|l|c|l|}
\hline NO & \multicolumn{1}{|c|}{ Nama Bank } & No & \multicolumn{1}{|}{ Nama Bank } \\
\hline 1 & PT. Bank Danamon Indonesia & 10 & PT. BPD Sumatera Utara \\
\hline 2 & PT. Bank Permata & 11 & PT. BPD Nagari \\
\hline 3 & PT. Bank CIMB Niaga & 12 & PT. BPD Riau Kepri \\
\hline 4 & PT. OCBC NISP & 13 & PT. BPD Sumatera Selatan dan Bangka Belitung \\
\hline 5 & PT. Bank Sinarmas & 14 & PT. BPD Kalimantan Selatan \\
\hline 6 & PT. Bank Tabungan Negara & 15 & PT. BPD Kalimantan Barat \\
\hline 7 & PT. BPD DKI & 16 & PT. BPD Kalimantan Timur dan Kalimantan Utara \\
\hline 8 & PT. BPD Jawa Tengah & 17 & PT. BPD Sulawesi Selatan dan Sulawesi Barat \\
\hline 9 & PT. BPD Jawa Timur & 18 & PT. BPD DIY \\
\hline
\end{tabular}

Penelitian ini termasuk jenis penelitian deskriptif dengan pendekatan kuantitatif. Data sekunder yang digunakan diambil dari annual report untuk pengungkapan ICG dan laporan keuangan triwulan ke-IV IC dimana masing-masing data terpisah dari data BUK induknya. 
Pengujian hipotesis dan analisis data yang digunakan dalam penelitian ini dilakukan dengan menggunakan metode regresi data panel.Fungsi dari regresi data panel dalam Baltagi (2008), yaitu :

Untuk $\mathrm{i}=1, . ., \ldots, 90 ; \mathrm{t}=1,2,3,4,5$

$$
\mathbf{Y}_{\mathrm{it}}=\boldsymbol{\alpha}+\mathbf{X}_{\mathrm{it}} \boldsymbol{\beta}+\varepsilon_{\mathrm{it}}
$$

$\mathrm{Y}_{i t} \quad$ = Variabel dependen pada unit observasi ke-i dan waktu ke-t

$\mathrm{X}_{\mathrm{it}} \quad=$ Variabel independen pada unit observasi ke-I dan waktu ke-t

$\alpha \quad=$ Konstanta

$\beta \quad=$ Parameter hasil estimasi

$\varepsilon_{\text {it }} \quad=$ Unsur gangguan variabel

\section{Definisi Operasional Variabel \\ Islamic Corporate Governance}

Berdasarkan faktor-faktor penilaian yang tercantum dalam PBI No. 11/33/PBI/2009, peneliti menyesuaikan Pedoman Good Governance Bisnis Syariah (GGBS) tahun 2011 yang diatur oleh KNKG dengan indikator yang sesuai dengan Unit Usaha Syariah (UUS). Berikut indikator yang dimaksud untuk mengukur kualitas ICG pada UUS:

Tabel 2

Indikator GGBS KNKG 2011

\begin{tabular}{|c|c|c|}
\hline Dimensi & Indikator & Jumlah \\
\hline \multirow{4}{*}{$\begin{array}{c}\text { Struktur dan } \\
\text { mekanisme kerja } \\
\text { DPS }\end{array}$} & 1. Nama anggota DPS & \multirow{4}{*}{4} \\
\hline & 2. Jumlah rapat yang dilakukan DPS & \\
\hline & 3. Jumlah kehadiran anggota DPS dalam rapat & \\
\hline & $\begin{array}{l}\text { 4. Mekanisme dan kriteria self assessment } \\
\text { tentang kinerja masing-masing anggota DPS }\end{array}$ & \\
\hline \multirow{11}{*}{$\begin{array}{c}\text { Struktur dan } \\
\text { mekanisme kerja } \\
\text { direksi }\end{array}$} & 1. Nama anggota direksi & \multirow{11}{*}{11} \\
\hline & 2. Jabatan Direksi & \\
\hline & 3. Fungsi masing-masing anggota Direksi. & \\
\hline & 4. Mekanisme pengambilan keputusan & \\
\hline & 5. Mekanisme pendelegasian wewenang. & \\
\hline & 6. Jumlah rapat yang dilakukan oleh Direksi & \\
\hline & 7. Jumlah kehadian. & \\
\hline & $\begin{array}{l}\text { 8. Mekanisme dan kriteria penilaian kinerja } \\
\text { para anggota Direksi. }\end{array}$ & \\
\hline & 9. Pengendalian Risiko & \\
\hline & 10. Sistem Pengawasan & \\
\hline & 11. Audit Internal & \\
\hline \multirow{8}{*}{ Etika Bisnis Syariah } & 1. Visi & \multirow{8}{*}{10} \\
\hline & 2. Misi & \\
\hline & 3. Nilai-nilai perusahaan & \\
\hline & 4. Pemegang saham mayoritas & \\
\hline & $\begin{array}{l}\text { 5. Kebijakan dan jumlah remunerasi DPS dan } \\
\text { Direksi. }\end{array}$ & \\
\hline & $\begin{array}{l}\text { 6. Transaksi dengan pihak yang memiliki } \\
\text { benturan kepentingan. }\end{array}$ & \\
\hline & $\begin{array}{l}\text { 7. Hasil penerapan GGBS yang dilaporkan } \\
\text { dalam rapat umum tahunan. }\end{array}$ & \\
\hline & 8. Pembayaran kewajiban zakat dan & \\
\hline
\end{tabular}




\begin{tabular}{|l|l|c|}
\hline \multirow{7}{*}{} & pelaksanaan corporate sosial responsibility & \\
\cline { 2 - 2 } & $\begin{array}{l}\text { 9. Pelaksanaan fungsi sebagai penerima dan } \\
\text { penyalur dana sosial lainnya berupa zakat, infak, } \\
\text { sedekah, dan wakaf }\end{array}$ & \\
\cline { 2 - 2 } & $\begin{array}{l}\text { 10. Kejadian luar biasa yang telah dialami } \\
\text { perusahaan dan dapat berpengaruh pada kinerja } \\
\text { perusahaan. }\end{array}$ & \\
\hline Total & \multicolumn{2}{|l|}{$\mathbf{2 5}$} \\
\hline
\end{tabular}

Sumber : Pedoman GGBS KNKG 2011

Peneliti memberikan skor 1 (satu) jika indikator yang dimaksud diungkap oleh UUS di dalam annual report. Sementara jika indikator yang dimaksud tidak diungkap oleh UUS di dalam annual report, peneliti memberikan skor 0 (nol).Kemudan, untuk menentukan tingkat pengungkapan ICG peneliti menggunakan rumus yang diadaptasi dari penelitian Yadiati (2017) sebagai berikut:

\section{Jumlah Item yang diungkapkan \\ ICG $=\quad \times 100 \%$ \\ Total skor maksimum}

\section{Intellectual Capital}

Intellectual Capital akan diukur dengan metode iB-VAIC yang merupakan modifikasi dari metode VAIC (Pulic, 2000) oleh Ulum (2013). Tahapan dalam menghitung iB-VAIC adalah sebagai berikut :

1) Menghitung Islamic Bank-Value Added (iB-VA) menggunakan rumus berikut :

$$
\text { iB-VA = OUT - IN }
$$

Keterangan :

iB-VA

OUT (output)

IN (input)

\section{: Islamic Bank-Value Added}

: Total Pendapatan

: Beban usaha/operasional dan beban non operasional kecuali beban tenaga kerja/karyawan

2) Menghitung Islamic Bank-Value Added Capital Employed (iBVACA) menggunakan rumus berikut:

$$
\text { iB-VACA }=\frac{V A}{C E}
$$

Keterangan :

iB-VACA

VA

CE

\author{
: Islamic Bank-Value Added Capital Employed \\ : Value Added \\ : Capital Employed : Dana yang tersedia (total ekuitas)
}

3) Menghitung Islamic Bank-Value Added Human Capital (iB-VAHU) menggunakan rumus berikut:

$$
\mathrm{iB}-V A H U=\frac{V A}{H C}
$$

Keterangan :

iB-VAHU : Islamic Bank-Value Added Human Capital 

VA
: Value Added
$\mathrm{HC}$
: Human Capital : Beban tenaga kerja/karyawan
4) Menghitung Islamic Bank-Value Added Intellectual Coefficient (iB-VAIC)

$$
\text { IB-VAIC = iB-VACA + iB-VAHU + iB-STVA }
$$

\section{Kinerja Keuangan}

Dalam penelitian ini penulis menggunakan Kinerja Keuangan sebagai variabel dependen. Kinerja Keuangan Unit Usaha Syariah (UUS) diproksikan dengan salah satu rasio profitabilitas, yaitu Return on Asset (ROA) yang dihitung dengan rumus berikut:

$$
\text { Return on Asset }=\frac{\text { Laba Bersih }}{\text { Total Aktiva }} \times 100 \%
$$

Findings

\section{FINDINGS AND DISCUSSIONS}

\section{Analisis Data}

Penelitian ini bertujuan untuk mengukur pengaruh pengungkapan ICG dan pengelolaan IC terhadap kinerja keuangan unit usaha syariah milik bank umum konvensional yang beroperasi di Indonesia.

\begin{tabular}{|c|c|c|}
\hline \multicolumn{3}{|c|}{ Rata-rata Pengungkapan ICG UUS } \\
\hline Peringkat & Nama Bank & $\begin{array}{c}\text { Rata-rata } \\
\text { Pengungkapan } \\
\text { ICG } \\
\text { 2013-2017 }\end{array}$ \\
\hline 1 & PT. Bank Permata & $56 \%$ \\
\hline 2 & PT. Bank CIMB Niaga & $49 \%$ \\
\hline 3 & PT. Bank Danamon & $48 \%$ \\
\hline 4 & PT. BPD Jawa Tengah & $45 \%$ \\
\hline 5 & $\begin{array}{l}\text { PT. BPD Sumatera Selatan dan Bangka } \\
\text { Belitung }\end{array}$ & $44 \%$ \\
\hline 6 & PT. Bank Sinarmas & $43 \%$ \\
\hline 7 & PT. BPD Daerah Istimewa Yogyakarta & $42 \%$ \\
\hline 8 & PT. BPD Kalimantan Selatan & $40 \%$ \\
\hline 9 & PT. BPD DKI & $39 \%$ \\
\hline 10 & PT. BPD Jawa Timur & $38 \%$ \\
\hline 11 & PT. BPD Kalimantan Barat & $37 \%$ \\
\hline 12 & PT. BPD Nagari & $36 \%$ \\
\hline 13 & PT. Bank Tabungan Negara (BTN) & $30 \%$ \\
\hline 14 & $\begin{array}{l}\text { PT. BPD Sulawesi Selatan dan } \\
\text { Sulawesi Barat }\end{array}$ & $29 \%$ \\
\hline 15 & PT. BPD Riau Kepri & $27 \%$ \\
\hline 16 & PT. BPD Sumatera Utara & $26 \%$ \\
\hline 17 & PT. OCBC NISP & $25 \%$ \\
\hline 18 & $\begin{array}{l}\text { PT. BPD Kalimantan Timur dan } \\
\text { Kalimantan Utara }\end{array}$ & $22 \%$ \\
\hline \multicolumn{2}{|c|}{ Rata-rata Keseluruhan } & $38 \%$ \\
\hline
\end{tabular}

\section{Tabel 3}

Rata-rata Pengungkapan ICG UUS

Tabel 3 menunjukkan rata-rata pengungkapan ICG masing-masing UUS dalam periode 2013-2017 serta rangkingnya. Terlihat Bank Permata memiliki rata-rata pengungkapan ICG tertinggi dengan rata-rata skor sebesar 56\%. Sedangkan BPD Kalimantan Timur dan 
Kalimantan Utara adalah yang terendah dengan rata-rata skor sebesar 22\%. Secara keseluruhan dalam periode 2013-2017 rata-rata skor tingkat pengungkapan ICG UUS sebesar $38 \%$.

\begin{tabular}{|c|c|c|c|}
\hline \multicolumn{4}{|c|}{$\begin{array}{c}\text { Tabel } 4 \\
\text { Peringkat Skor ICG UUS 2013-2017 }\end{array}$} \\
\hline Nama Bank & $\begin{array}{c}\text { Struktur dan } \\
\text { mekanisme } \\
\text { kerja DPS } \\
\text { (4) }\end{array}$ & $\begin{array}{c}\text { Struktur dan } \\
\text { mekanisme } \\
\text { kerja } \\
\text { Direktur } \\
(11) \\
\end{array}$ & $\begin{array}{c}\text { Etika } \\
\text { Bisnis } \\
\text { Syariah } \\
(10)\end{array}$ \\
\hline PT. Bank Permata & $75 \%$ & $36 \%$ & $70 \%$ \\
\hline PT. Bank CIMB Niaga & $75 \%$ & $36 \%$ & $52 \%$ \\
\hline PT. Bank Danamon & $75 \%$ & $36 \%$ & $50 \%$ \\
\hline PT. BPD Jawa Tengah & $75 \%$ & $27 \%$ & $52 \%$ \\
\hline $\begin{array}{l}\text { PT. BPD Sumatera Selatan dan } \\
\text { Bangka Belitung }\end{array}$ & $75 \%$ & $25 \%$ & $52 \%$ \\
\hline $\begin{array}{l}\text { PT. BPD Daerah Istimewa } \\
\text { Yogyakarta }\end{array}$ & $75 \%$ & $22 \%$ & $52 \%$ \\
\hline PT. Bank Sinarmas & $65 \%$ & $35 \%$ & $44 \%$ \\
\hline PT. BPD Kalimantan Selatan & $75 \%$ & $27 \%$ & $40 \%$ \\
\hline PT. BPD Jawa Timur & $75 \%$ & $20 \%$ & $44 \%$ \\
\hline PT. BPD DKI & $64 \%$ & $42 \%$ & $26 \%$ \\
\hline PT. BPD Kalimantan Barat & $75 \%$ & $36 \%$ & $22 \%$ \\
\hline PT. BPD Nagari & $75 \%$ & $27 \%$ & $30 \%$ \\
\hline PT. Bank Tabungan Negara & $75 \%$ & $13 \%$ & $32 \%$ \\
\hline $\begin{array}{l}\text { PT. BPD Sulawesi Selatan dan } \\
\text { Sulawesi Barat }\end{array}$ & $65 \%$ & $22 \%$ & $22 \%$ \\
\hline PT. BPD Riau Kepri & $50 \%$ & $25 \%$ & $20 \%$ \\
\hline PT. BPD Sumatera Utara & $25 \%$ & $31 \%$ & $22 \%$ \\
\hline PT. OCBC NISP & $50 \%$ & $22 \%$ & $18 \%$ \\
\hline $\begin{array}{l}\text { PT. BPD Kalimantan Timur dan } \\
\text { Kalimantan Utara }\end{array}$ & $30 \%$ & $22 \%$ & $18 \%$ \\
\hline Rata-rata Keseluruhan & $65 \%$ & $28 \%$ & $37 \%$ \\
\hline
\end{tabular}

Sumber : Data Olahan Peneliti

Tabel 4menunjukkan rata-rata skor pengungkapan ICG UUS selama periode 2013-2017 setiap dimensi. Pengungkapan ICG tertinggi adalah mengenai struktur dan mekanisme kerja DPS sebesar 65\%. Sedangkan pengungkapan terendah adalah mengenai struktur dan mekanisme kerja direktur sebesar 28\%. Operasional UUS merupakan salah satu bagian dari pengembangan bisnis bank umum konvensional, sehingga banyak kebijakan tata kelola UUS menyatu dengan bank umum konvensional dan hanya diungkapkan pada bagian pengungkapan tata kelola bank umum konvensional. Contohnya, pengungkapan struktur dan mekanisme kinerja direktur UUS dan visi dan misi perusahaan. Inilah yang menyebabkan rendahnya pengungkapan ICG pada UUS. iB-VAIC adalah jumlah dari 3 komponen utama, yaitu capital employed, human capital dan structural capital. iB-VAIC menggambarkan kemampuan modal intelektual bank syariah untuk menciptakan value added.

Tabel 5 di bawah menunjukkan rata-rata nilai iB-VAIC UUS dalam periode 2013-2017. Rata-rata UUS memiliki nilai iB-VAIC diatas 3,0 yaitu sebesar 4,1 dalam periode observasi. 
UUS yang berhasil mencapai nilai iB-VAIC diatas 3,0 dapat dikategorikan berada di posisi top performers yang berarti telah mampu mengelola intellectual capital yang dimilikinya secara efisien hingga memberikan value added kepada perusahaan.

\section{Grafik 1}

Rata-rata iB-VAIC UUS 2013-2017

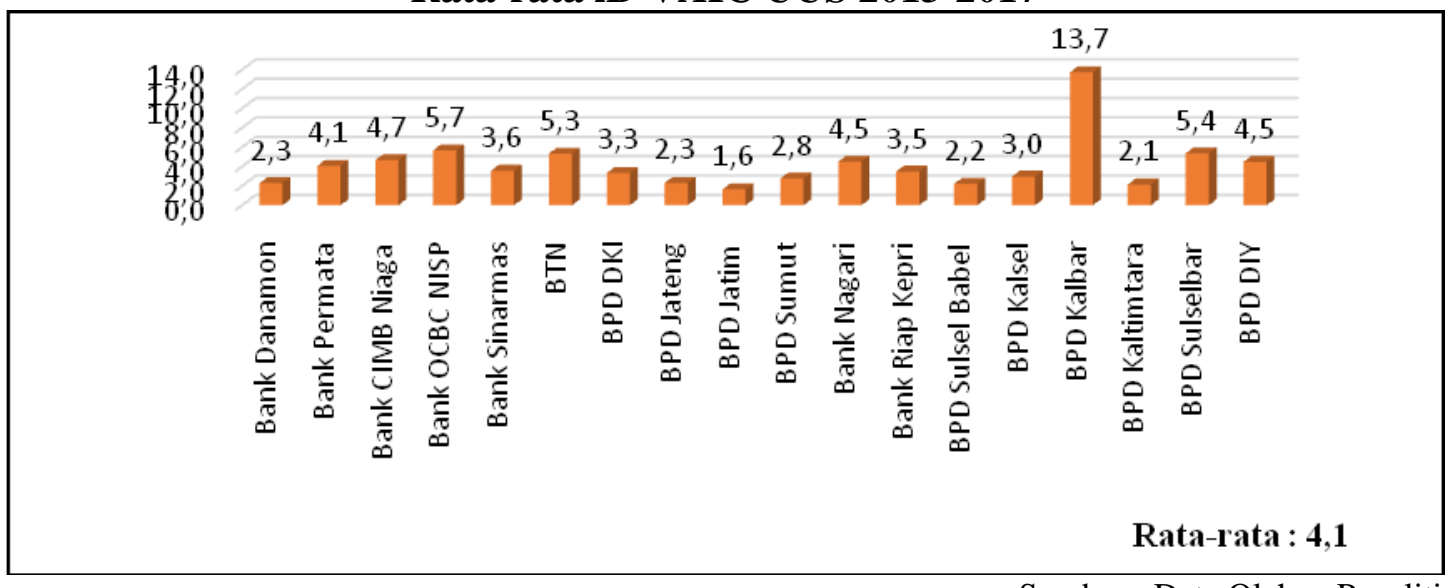

Sumber : Data Olahan Peneliti

UUS BPD Kalimantan Barat adalah yang paling baik dalam mengelola intellectual capital (IC) miliknyadengan nilai rata-rata sebesar 13,7.UUS BPD Kalimantan Barat diketahui sangat efisiendalam memanfaatkan kompetensi karyawannya, sehingga human capitalsebagai salah satu komponen IC dapat memberikan nilai paling besar terhadap value added. UUS BPD Kalimantan Barat menghasilkan pendapatan yang besar dari kegiatan penyaluran dana meski mengeluarkan biaya tenaga kerja yang kecil jika dibanding UUS lainnya.

\section{Analisis Regresi Data Panel}

Untuk melakukan analisis data panel, terlebih dahulu dilakukan penentuan metode estimasi dengan melakukan uji chow, uji hausman, dan uji lagrangian multiplier. Pengujian dilakukan dengan membandingkan nilai probabilitas ( $p$-value) dengan nilai signifikansi yang digunakan dalam penelitian ini, yaitu 0,05. Jika $p$-value $<0,05$ maka $\mathrm{H} 0$ ditolak dan jika $p$ value $>0,05$ maka $\mathrm{H} 0$ diterima.Setelah melalui 3 pengujian tersebut didapatkan bahwa model random effect adalah yang paling sesuai untuk penelitian ini. Menurut Gujarati \& Porter (2009), apabila berdasarkan pemilihan metode estimasi menghasilkan model random effect yang sesuai untuk penelitian dengan persamaan regresi data panel, maka tidak perlu dilakukan uji asumsi klasik. Karena persamaan yang memenuhi asumsi klasik hanya persamaan yang menggunakan metode Generalized Least Square (GLS) dan dalam Eviews model estimasi yang menggunakan metode GLS hanya model random effect. Dengan demikian dalam penelitian ini peneliti tidak melakukan uji asumsi klasik untuk melakukan analisis statistik selanjutnya. 


\section{Uji Partial (T-test)}

Tabel 5 Uji Parsial (T-test)

\begin{tabular}{crrrr}
\hline Variable & Coefficient & Std. Error & t-Statistic & Prob. \\
\hline \hline C & 0.032209 & 0.008022 & 4.015290 & 0.0001 \\
ICG & 0.007515 & 0.011764 & 0.638802 & 0.5247 \\
IB_VAIC & 0.002436 & 0.000448 & 5.440281 & 0.0000 \\
NPF & 0.030447 & 0.053129 & 0.573077 & 0.5681 \\
FDR & 0.005054 & 0.002276 & 2.221138 & 0.0290 \\
BOPO & -0.034772 & 0.005967 & -5.826933 & 0.0000 \\
\hline \hline
\end{tabular}

Sumber : Olahan data peneliti, using Eviews

Berdasarkan tabel 5 dapat dilihat coefficient Islamic Corporate Governance (ICG) sebesar 0,007515 dengan nilai probabilitas 0,5247 dimana nilai probabilitasnya lebih besar dari nilai signifikansi yang digunakan dalam penelitian ini, yaitu 0,05.Dari hal tersebut dapat disimpulkan bahwa data ICG secara parsial tidak berpengaruh signifikan terhadap kinerja keuangan UUS dalam periode 2013-2017. Selanjutnya, coefficient iB-VAIC sebesar 0,002436 dengan nilai probabilitas 0,0000 dimana nilai probabilitasnya lebih kecil dari nilai signifikansi yang digunakan dalam penelitian ini, yaitu 0,05. Dari hal tersebut dapat disimpulkan bahwa secara parsial iB-VAIC berpengaruh positif signifikan terhadap kinerja keuanganUUS. Variabel kontrol yang digunakan untuk memperjelas pengaruh dari 2 variabel independen dalam penelitian ini yaitu, NPF, FDR dan BOPO memiliki nilai probabilitas masing-masing $0,5681,0,005054$, dan 0,0000 . Hanya NPF yang memiliki nilai probabilitas lebih besar dari nilai signifikansi sebesar 0,05. Maka dapat disimpulkan bahwa NPF tidak berpengaruh signifikan terhadap keuangan UUS dalam periode 2013-2017, sedangkan FDR berpengaruh positif dan BOPO berpengaruh negatif.

\section{Uji Simultan (F-test)}

\section{Tabel 5 Uji Parsial (T-test)}

Weighted Statistics

\begin{tabular}{llll}
\hline \hline & & & \\
R-squared & 0.624681 & Mean dependent var & 0.013103 \\
Adjusted R-squared & 0.602340 & S.D. dependent var & 0.013694 \\
S.E. of regression & 0.008635 & Sum squared resid & 0.006264 \\
F-statistic & 27.96191 & Durbin-Watson stat & 1.710376 \\
Prob(F-statistic) & 0.000000 & & \\
\hline \hline
\end{tabular}

Sumber : Olahan data peneliti, using Eviews

Berdasarkan tabel 5 diketahui nilai probabilitas (F-statistic) dari semua variabel independen dalam penelitian ini sebesar 0,000000 dimana nilai probabilitas tersebut lebih kecil dari nilai signifikansi sebesar 0,05. Dapat diartikan bahwa semua variabel independen dalam model secara simultan berpengaruh terhadap variabel dependen. Dari tabel juga terlihat nilai adjusted $R$-squared sebesar 0,602340. Hal tersebut berarti 60,2\% kinerja keuangan (ROA) dapat dijelaskan oleh variabel independen berupa ICG dan iB-VAIC dan variabel kontrol berupa NPF, FDR, dan BOPO. Sedangkan sisanya sebesar 39,8\% dijelaskan oleh variabel lain di luar penelitian ini. 


\section{Discussions \\ Pengaruh ICG Terhadap Kinerja Keuangan UUS}

Hipotesis pertama yang diajukan pada penelitian ini adalah semakin baik pengungkapan Islamic Corporate Governance, maka semakin baik kinerja keuangan Unit Usaha Syariah periode 2013-2017. Berdasarkan hasil uji statistikhipotesis ini ditolak. ICG UUS yang dikomunikasikan dalam annual report tidak berpengaruh signifikan terhadap kinerja keuangan UUS. Hasil ini bertolak belakang dengan penelitian yang dilakukan oleh Yadiati et al (2017), Farag et al (2017) dan Meilani (2015) yang menyimpulkan bahwa ICG berpengaruh positif signifikan terhadap kinerja keuangan bank Islam. Namun, hasil ini sejalan dengan penelitian yang dilakukan oleh Ajili dan Bouri (2017), Siswanti (2016) dan Syafei (2015) yang juga menemukan bahwa ICG tidak berpengariuh signifikan terhadap kinerja keuangan bank Islam. Tidak berpengaruhnya ICG terhadap kinerja diduga oleh terbatasnya informasi yang diungkapkan bank umum konvensional untuk UUS yang dioperasikannya. Informasi mengenai kebijakan tata kelola yang bercampur antara bank umum konvensional dan UUS mengakibatkan masyarakat ragu pada prinsip-prinsip Islam yang diterapkan pada UUS. Rendahnya pengungkapan ICG menyiratkan bahwa corporate governance pada UUS tidak menjadi hal yang harus dikomunikasikan kepada stakeholderskarena operasional UUS bukan kegiatan yang utama melainkan hanya salah satu bagian dari pengembangan usaha bank umum konvensional untuk mendapatkan keuntungan. Memperbaiki tata kelola perusahaan di bank syariah merupakan ukuran sangat penting yang harus diambil agar industri dapat terus tumbuh dengan efisien dan tetap kompetitif (Samra, 2016) karena tata lelola yang lemah menyebabkan perusahaan rentan terhadap penurunan ekonomi dan kemungkinan untuk jatuh ke dalam kesulitan keuangan akansemakin besar (Hassan Al-Tamimi, 2012). Tata kelola perusahaan yang efektif pada perusahaan perbankan akan mengarah pada peningkatan efisiensi dalam kegiatan bank, pengurangan risiko, peningkatan pertumbuhan bank di pasar, peningkatan kepercayaan investor, stabilisasi ekonomi, dan rendahnya biaya modal untuk kegiatan operasionalnya (Marcinkowska, 2012 dalam Ghaffar, 2014).

\section{Pengaruh Intellectual Capital Terhadap Kinerja Keuangan UUS}

Hipotesis kedua yang diajukan pada penelitian ini adalah semakin efisien pengelolaan intellectual capital maka semakin tinggi kinerja keuangan Unit Usaha Syariah periode 20132017. Berdasarkan hasil uji statistik disimpulkan bahwa intellectual capitalterbukti berpengaruh positif signifikan terhadap kinerja keuangan UUS dan hipotesis kedua penelitian ini diterima. Hasil analisis statistik untuk penelitian ini sejalan dengan hasil penelitian sebelumnya oleh Nawaz dan Haniffa (2017), Ozkan et al (2017), Setianto dan Sukmana (2016), Al-Musali dan Ismail (2014) yang juga menemukan bahwa Intellectual Capital berpengaruh positif signifikan tehadap kinerja keuangan bank syariah. UUS mengelola IC dengan baik sehingga secara efisien dapat menciptakan valueadded bagi perusahaan. Selama periode 2013-2017 rata-rata UUS memiliki nilai iB-VAIC sebesar 4,1 yang berarti UUS dikategorikan sebagai top performance dalam efisiensinya mengelola IC. Dari data yang dikumpulkan diketahui bawahwa value added UUS sebagian besar berasal dari human capital, diikuti ikuti oleh structural capital dan capital employed. Konsep human capital adalah sesuatu yang tidak dapat ditransfer dari satu orang ke orang lain, tetapi perusahaan harus berinvestasi untuk mendapatkannya dan mengembangkannya hingga dapat diakui sebagai sumber keunggulan kompetitif bagi industri perbankan yang bergerak di bidang penyediaan jasa keuangan bagi masyarakat untuk menciptakan value added (Thaib, 2013). Namun, hal ini tidak berarti bahwa komponen lain menjadi hal yang tidak perlu untuk ditingkatkan. Intellectual Capital adalah gabungan dari aset tidak berwujud dan financial yang saling mendukung perusahaan menjalankan aktivitas operasinya.Ketika modal 
intelektual di ditransformasikan secara efisien dan seimbang maka akan mendorong penciptaan nilai dan kinerja yang tinggi sehingga memperoleh keunggulan kompetitif dan berkelanjutan (Roos dan Roos, 1997; Bontis, 1998 dalam Long Kweh et al, 2013). Secara keseluruhan, kedua variabel independen yang dimasukkan ke dalam model menunjukkan pengaruh positif dan signifikan terhadap kinerja keuangan UUS dalam periode 2013-2017. Pengaruh dari masing-masing variabel telah dikontrol dengan menambahkan NPF, FDR dan BOPO ke dalam model.

\section{Simpulan}

Islamic Corporate Governance tidak berpengaruh terhadap kinerja keuangan UUS.Tidak berpengaruhnya ICG, karena informasi dan pengungkapan mengenai ICG, serta informasi tata kelola bercampur antara bank konvensional untuk UUS yang dioperasikannya, hal ini pula yang mengakibatkan pengungkapan ICG di UUS sangar rendah. Intellectual Capital berpengaruh positif terhadap kinerja keuangan UUS, berpengaruhnya IC terhadap UUS , dikerenakan semua perbankan yang memiliki UUS ataupun tidak memgelola IC dengan baik sehingga menciptakan value added bagi perusahaan, UUS diketegorikan memiliki top performance dalam menciptakan efisiensi untuk pengelolaan IC, terutama human capital.

\section{DAFTAR PUSTAKA}

Abdullah, W. A. W., Percy, M., \& Stewart, J. 2015. Determinants Of Voluntary Corporate Governance Disclosure: Evidence From Islamic Banks In The Southeast Asian And The Gulf Cooperation Council Regions. Journal Of Contemporary Accounting \& Economics, 11(3): 262-279.

Ajili, H., \& Bouri, A. 2018. Corporate governance quality of Islamic banks: measurement and effect on financial performance. International Journal of Islamic and Middle Eastern Finance and Management. Vol. 11 Issue: 3: .470-487

Al-Arif, M., Nachrowi, N., Nasution, M., \& Mahmud, T. M. 2017. The Islamic banking spinoff: Lessons from Indonesian Islamic banking experiences. JKAU: Islamic Econ., Vol. 30 No. 2: 117-133

Albassam, W. M., \& Ntim, C. G. 2017. The effect of Islamic values on voluntary corporate governance disclosure: The case of Saudi-listed firms. Journal of Islamic Accounting and Business Research, 8(2): 182-202.

Al-Musali, M. A. K., \& Ismail, K. N. I. K. 2014. Intellectual Capital And Its Effect On Financial Performance Of Banks: Evidence From Saudi Arabia. Procedia-Social And Behavioral Sciences, 164: 201-207.

Beekun, R. I. 1997. Islamic business ethics (No. 2). International Institute of Islamic Thought (IIIT).

Bhatti, M., \& Bhatti, M. I. 2010. Toward understanding Islamic corporate governance issues in Islamic finance. Asian Politics \& Policy, Vol. 2, No. 1: 25-38.

Bontis, Keow, dan Richardson. 2000. Intellectual Capital And Bussines Perfomance In Malaysian Industries. Journal Of Intellectual Capital, Vol. 1 No. 1: 85-100.

Chen, M. C., Cheng, S. J., dan Hwang, Y. 2005. An Empirical Investigation Of The Relationship Between Intellectual Capital And Firms' Market Value And Financial Performance. Journal Of Intellectual Capital, Vol. 6, No. 2: 159-176.

Darmadi, S. 2013. Corporate governance disclosure in the annual report: An exploratory study on Indonesian Islamic banks. Humanomics, Vol. 29, No. 1: 4-23.

Dewanata, P., Hamidah, H., \& Ahmad, G. N. 2016. The Effect Of Intellectual Capital And Islamicity Performance Index To The Performance Of Islamic Bank In Indonesia 20102014 Periods. Jrmsi-Jurnal Riset Manajemen Sains Indonesia, Vol. 7, No. 2: 259-278. 
El Junusi, R. 2012. Implementasi Shariah Governance Serta Implikasinya Terhadap Reputasi Dan Kepercayaan Bank Syariah. Al-Tahrir: Jurnal Pemikiran Islam, Vol. 12, No. 1: 87111.

Farag, H., Mallin, C., \& Ow-Yong, K. 2018. Corporate governance in Islamic banks: New insights for dual board structure and agency relationships. Journal of International Financial Markets, Institutions and Money, 54, 59-77.

Ferdyant, F., \& Takidah, E. 2014. Pengaruh Kualitas Penerapan Good Corporate Governance Dan Risiko Pembiayaan Terhadap Profitabilitas Perbankan Syariah. Jurnal Dinamika Akuntansi Dan Bisnis, Vol. 1, No. 2: 134-149.

Ghaffar, A. 2014. Relationship of Islamic Bank's Profitability with Corporate Governance Practices. European Journal of Business and Management, 6(17).

Habiburrachman. 2008. Kajian tentang Pentingnya Intellectual Capital dalam mendukung Peningkatan Kinerja Perusahaan. Jurnal Administrasi dan Bisnis, Vol 2, No.1.

Hasan, Z. 2009. Corporate Governance: Western And Islamic Perspectives. International Review of Business Research Papers, Vol. 5, No. 1: 277-293.

Hassan Al-Tamimi, H. A. 2012. The effects of corporate governance on performance and financial distress: The experience of UAE national banks. Journal of Financial Regulation and Compliance, 20 (2), 169-181.

Kalkan, A., Bozkurt, Ö. Ç., \& Arman, M. (2014). The impacts of intellectual capital, innovation and organizational strategy on firm performance. Procedia-Social and Behavioral Sciences, 150, 700-707.

Long Kweh, Q., Chuann Chan, Y., \& Wei Kiong Ting, I. 2013. Measuring Intellectual Capital Efficiency In The Malaysian Software Sector. Journal of Intellectual Capital, 14(2), 310-324.

Maradita, A. 2014. Karakteristik Good Corporate Governance Pada Bank Syariah dan Bank Konvensional. Yuridika, Vol. 29, No. 2.

Meilani, S. E. R. 2015. Hubungan Penerapan Good Governance Business Syariah Terhadap Islamicity Financial Performance Index Bank Syariah Di Indonesia.

Nawaz, T., \& Haniffa, R. 2017. Determinants Of Financial Performance Of Islamic Banks: An Intellectual Capital Perspective. Journal Of Islamic Accounting And Business Research, Vol. 8, No. 2: 130-142.

Novitasary, R., \& Permatasari, I. 2014. Pengaruh Implementasi Good Corporate Governance Terhadap Permodalan Dan Kinerja Perbankan Di Indonesia: Manajemen Risiko Sebagai Variabel Intervening. Jurnal Ekonomi Kuantitatif Terapan, Vol. 7, No. 1.

Ozkan, N., Cakan, S., \& Kayacan, M. 2017. Intellectual Capital And Financial Performance: A Study Of The Turkish Banking Sector. Borsa Istanbul Review, Vol. 17, No. 3: 190-198.

Pulic, A. 2000. "Basic information on VAIC "TM". Diakses pada 13 April 2018. www.vaicon.net.

Rini, S., \& Boedi, S. 2017. Pengaruh Intellectual Capital Terhadap Kinerja Keuangan Perbankan. Jurnal Manajemen dan Akuntansi, Vol. 17, No. 1.

Setianto, R. H., dan Sukmana, R. 2016. Intellectual Capital and Islamic Banks Performance; Evidence from Indonesia and Malaysia. Iqtishadia: Jurnal Kajian Ekonomi dan Bisnis Islam STAIN Kudus, Vol. 9, No. 2: 376-397.

Siswanti, I. 2016. Implementasi Good Corporate Governance pada Kinerja Bank Syariah. Jurnal Akuntansi Multiparadigma, Vol. 7, No. 2: 307-321.

Sunardi, N. 2017. Determinan Intelectual Capital dengan Pendekatan iB-VAIC TM Terhadap Efisiensi Biaya Implikasinya Pada Profitabilitas Perbankan Syariah di Indonesia. Jurnal Sekuritas (Saham, Ekonomi, Keuangan dan Investasi), Vol. 1, No. 2. 
Syafei, A. W. 2015. Analisis Pengaruh Penerapan Good Governance Bisnis Syariah (GGBS) terhadap Kemampulabaan (Studi Perusahaan yang Terdaftar di JII 2011). Jurnal AlAzhar Indonesia Seri Pranata Sosial, 2(2), 74-86.

Thaib, F. 2013. Value Added Intellectual Capital (VAHU, VACA, STVA) Pengaruhnya Terhadap Kinerja Keuangan Bank Pemerintah Periode 2007-2011. Jurnal EMBA: Jurnal Riset Ekonomi, Manajemen, Bisnis dan Akuntansi, 1(3).

Triyuwono, Iwan. 2007. Menggagas Sing Liyan Untuk Formulasi Nilai Tambah Syariah. Simposium Nasional Akuntansi X. UNHAS Makasar.

Ulum, I. 2013. iB-VAIC: Model Pengukuran Kinerja Intellectual Capital Perbankan Syariah di Indonesia. Jurnal Infersi (terakreditasi), Vol. 7, No. 1: 183-204.

Yadiati, W., Gustani., dan Amrania, G. 2017. The Effect of Islamic Corporate Governance (ICG) and Islamic Corporate Social Responsibility (ICSR) Disclosures on Market Discipline with Financial Performance Used as Intervening Variables (Empirical Study on Shariah based Banks Operating in QISMUT Countries). International Journal of Applied Business and Economic Research, Vol. 15, No. 24: 119-141. ISSN : 0972-7302. 